\title{
PENERAPAN PROGRAM AKADEMIK DAN APLIKASI SIAKAD TERHADAP MUTU PELAYANAN MAHASISWA DI FAKULTAS ILMU TARBIYAH DAN KEGURUAN IAIN SULTAN AMAI GORONTALO
}

\author{
Irma Purnima Niha ${ }^{1}$ Buhari Luneto ${ }^{2}{\text { Razak } \text { Umar }^{3}}^{3}$ \\ ${ }^{123}$ Institut Agama Islam Negeri Sultan Amai Gorontalo \\ email: irmaniha@gmail.com
}

\begin{abstract}
Abstrak
Tujuan penelitian ini yaitu : 1) untuk mengetahui pengaruh Program Akademik terhadap Mutu Pelayanan Mahasiswa 2) untuk mengetahui pengaruh Aplikasi SIAKAD terhadap Mutu Pelayanan Mahasiswa Di Fakultas Ilmu Tarbiyah dan Keguruan IAIN Sultan Amai Gorontalo.Penelitian ini menggunakan jenis metode penelitian kuantitatif. Populasi dalam penelitian ini berjumlah 2.140 orang dengan sampel yang diteliti berjumlah 96 orang. Selanjutnya pengumpulan data penulis menggunakan angket, dan jenis analisis yang digunakan yaitu berupa analisis regresi Linear Sederhana dan Regresi Linear Berganda. Hasil penelitian dan pembahasan, menujukkan bahwa Program Akademik dan Aplikasi SIAKAD berpengaruh Terhadap Muu Pelayanan Mahasiswa setelah diuji menggunakan rumus Regresi sederhana masing-masing $Y=6.461+1.189 X_{1}$ dan $Y=20.292+1.562 X_{2}$. Hal ini membuktikan bahwa Program Akademik dan Aplikasi SIAKAD memiliki pengaruh yang signifikan terhadap Mutu Pelayanan Mahasiswa serta mengakibatkan peningkatan masing-masing sebesar 1.189 dan 1.562 pada konstanta 25.791 dan 20.292.hal ini juga dibuktikan dengan pengujian Hipotesis dimana uji parsial masing masing $t_{\text {hitung }}>t_{\text {tabel }}$ yaitu X1 $(2.684>1,989)$ dan X2 (5,408 > 1,989). Maka HO ditolak. Demikian juga dengan menggunakan rumus analisis Regresi berganda $Y=a+b_{1} X_{1+} b_{2} X_{2}=9,952+0,478 X_{1}+1,142 X_{2}$, maka pengujian hipotesis secara bersama-sama di dapat $F_{\text {hitung }}>T_{\text {tabel }}$ atau $63.962>1,989$, maka HO di tolak dan $\mathrm{Ha}$ di terima. Hasil penelitian ini menunjukkan bahwa faktor Program Akademik dan Aplikasi SIAKAD memberikan sumbangan efektif sebesar 57,9\%, dapat diartikan Mutu Pelayanan Mahasiswa dipengaruhi oleh Program Akademik dan Aplikasi SIAKAD sedangkan 42,1\% merupakan pengaruh dari luar variabel yang tidak dimasukan dalam model penelitian ini.
\end{abstract}

Kata kunci: Program Akademik, Aplikasi SIAKAD, Mutu Pelayanan Mahasiswa 


\section{PENDAHULUAN}

Layanan yang berkualitas adalah alternatif yang rasional dalam mengatasi permasalahan yang ada. Keberhasilan suatu jasa pelayanan dalam mencapai tujuannya sangat tergantung pada konsumen. Dalam pekerjaan teknis administrasi, pelayanan merupakan bagian dari aktifitas yang berupa mekanis. Layanan pada dasarnya adalah orang yang memberikan atau mengurus apa yang di butuhkan oleh orang lain baik berupa barang atau jasa kepada pengguna jasa yang membutuhkan suatu informasi. Mutu pelayanan merupakan pencapaian standar harapan pelanggan untuk memenuhi hal yang berkaitan dengan keinginan mereka.

Kualitas pelayanan yang dikemukakan Fitzsimmons mengatakan bahwa kualitas pelayanan merupakan suatu yang kompleks, sehingga cocok untuk dijadikan dimensi kemudian dijabarkan melalui indikator - indikator untuk menentukan sejauh mana kualitas pelayanan dalam penelitian, yaitu :

1) Reability, kemauan untuk memberikan secara tepat dan benar, jenis pelayanan yang telah dijanjikan kepada konsumen atau pelanggan

2) Responsiviness, kesadaran atau keinginan untuk membantu konsumen dalam memberikan pelayanan yang cepat

3) Assurance, pengetahuan atau wawasan, kesopansantunan, keperayaan diri dari pemberi layanan, serta respek terhadap konsumen

4) Empathy, kemauan pemberi layanan untuk melakukan pendekatan, meberikan perlindungan, serta berusaha untuk mengetahui kringinan dan kebutuhan konsumen

5) Tangibles, penampilan para pegawai dan fasilitas fisik lainnya, serta peralatan atau perlengkapan yang menunjang pelayanan. ${ }^{1}$

Sumber daya manusia merupakan satu-satunya sumber yang memiliki akal perasaan, keinginan, keterampilan, pengetahuan, dorongan, daya, dan karya (rasio, rasa dan karsa). Semua potensi SDM tersebut berpengaruh terhadap upaya organisasi dalam mencapai tujuan. ${ }^{2}$ Adapun sumber daya manusia yang terlibat pada lembaga pendidikan yaitu tenaga pendidik (guru,dosen) dan tenaga kependidikan meliputi sistem keadministrasian (tata usaha). Demi menunjang terlaksananya kegiatan belajar mengajar diperlukan suatu bagian yang mendukung kegiatan tersebut ialah ketatausahaan. Tata usaha melayani pelaksanaan sesuatu pekerjaan operatif dengan menyediakan berbagai keterangan yang diperlukan. Keterangan ini memudahkan tercapainya tujuan yang

\footnotetext{
${ }^{1}$ Riduwan, Metode dan Teknik Menyusun Tesis(Bandung: Alfabeta,2010) Cet. VII .h 20

${ }^{2}$ Edy Sutrisno, Manajemen Sumber Daya Manusia, Cetakan ke-5, (Jakarta: Kencana,
} 2013), h.3 
diinginkan atau memungkinkan penyelesaian pekerjaan operatif yang bersangkutan secara lebih baik. ${ }^{3}$

Pendidikan memang jalur yang harus di tempuh untuk ikut dalam perkembangan zaman. Pendidikan merupakan salah satu usaha pemerintah di dalam meningkatkan kualitas sumber daya manusia demi tercapainya pembangunaan di berbagai bidang, baik di bidang agama maupun umum. Perguruan tinggi berfungsi untuk menyelenggarakan pendidikan, penelitian, dan pengabdian kepada masyarakat. Dalam pasal 4 ayat (1) PP No 60 tahun 1999 tentang Pendidikan Tinggi. menyebutkan bahwa pendidikan tinggi terdiri atas pendidikan akademik dan profesional. Pasal ini menyebutkan bahwa pendidikan akademik mengutamakan peningkatan mutu dan memperluas wawasan ilmu pengetahuan dan diselenggarakan oleh sekolah tinggi, institut dan universitas. Sementara pada pasal 4 ayat (3) disebutkan bahwa pendidikan profesional mengutamakan peningkatan kemampuan menerapkan ilmu pengetahuan dan diselenggarakan oleh politeknik, sekolah tinggi, insitut dan universitas. ${ }^{4}$

Setiap perguruan tinggi memiliki program akademik sebagai penunjang pelaksanaan kegiatan yang harus diikuti oleh semua pihak yang terkait dalam sistem kelembagaan. Sebagai suatu sistem, efektivitas dan efisiensi institut akan sangat bergantung pada dua hal. Pertama, seberapa jauh pekerjaan-pekerjaan rutin yang direalisasikan dan dijaga keberfungsiannya menurut standar yang ada, kedua seberapa jauh pemikiran baru yang berorientasikan untuk pengembangan kampus. ${ }^{5}$

Program akademik memuat tentang visi misi,tujuan,struktur organisasi, kurikulum, layanan penunjang Tri darma Perguruan Tinggi,Struktur organisasi. Program pendidikan meliputi jenis program pendidikan,jenis program studi, program sarjana. Pengelolaan penyelenggaraan program pendidikan meliputi ketentuan pengelolaan, bimbingan dan konseling. Sistem administrasi akademik meliputi sistem kredit semester (SKS),Sistem penerimaan mahasiswa baru, sistem administrasi mahasiswa, system penyelenggaraan perkuliahan, sangsi akademik dan skorsing, jadwal kegiatan akademik. Ketentuan akademik program sarjana meliputi praktek kerja lapangan program S1,pengajuan judul dan seminar proposal,ujian komprehensif,penulisan skripsi. Penilaian hasil belajar meliputi pengertian dan tujuan evaluasi, jenis -jenis evaluasi. Kalender akademik disusun menjelang tahun akademik baru. Dalam menyusun kalender akademik perlu memperhatikan prinsip organisasi, integrasi dan sinkronisasi semua kegiatan akademik dan administrasi yang akan dilakukan dalam satu tahun akademik.

Pada Era globalisasi sekarang ini, teknologi informasi berperan penting dalam memperbaiki kinerja suatu organisasi. Pengunaannya tidak hanya sebagai proses otomatisasi terhadap akses informasi, tetapi juga menciptakan akurasi, kecepatan dan

${ }^{3}$ Daryanto, Administrasi Pendidikan, (Jakarta: Rineka Cipta, 2011), h. 94-95

${ }^{4}$ Sudiyono, Manajemen Pendidikan Tinggi,( Jakarta:Rineka Cipta, 2004)h. 3

5 Ridwan Tohopi dkk, Pedoman Akademik IAIN Sultan Amai Gorontalo.(Gorontalo :2014)h. iii 
kelengkapan suatu sistem yang terintegrasi, sehingga proses organisasi yang terjadi akan efisien, terukur dan fleksibel.

Fasilitas yang berkualitas tentu menjadi nilai tambah bagi perguruan tinggi. Perkembangan kualitas perguruan tinggi harus sejalan penggunaan teknologi informasi. Salah satunya adalah pemilihan sistem pengolahan data yang baik. Seluruh Perguruan Tinggi di Indonesia mulai berbenah dalam pengolahan data dan pelayanan akademiknya. Sebagian besar perguruan tinggi sudah menggunakan Sistem Informasi Akademik berbasis digital elektronik dengan pertimbangan efektifitas dan efisiensi penanganan datanya. Dengan memiliki sistem informasi terintegrasi, perguruan tinggi akan lebih mudah melakukan pengolahan data mahasiswa. Di sisi lain, mahasiswa juga akan merasakan kemudahan untuk melakukan pendaftaran, pembayaran, maupun melihat laporan akademiknya.

Sistem Informasi Akademik IAIN Sultan Amai Gorontalo bertujuan untuk memberikan informasi tentang kepentingan akademik. Misalnya : data mahasiswa, KRS (Kartu Rencana Studi), KHS (Kartu Hasil Studi), laporan nilai mahasiswa, dll. Sistem informasi akademik dapat diakses dan dimanfaatkan oleh umum dan civitas akademika, mulai dari mahasiswa, dosen, staf Akademik, staf keuangan, hingga pimpinan atau manajemen. Pengelolaan data mahasiswa yang di input melalui Sistem Informasi Akademik IAIN Sultan Amai Gorontalo antara lain data Mahasiswa, data dosen, data mata kuliah,KRS (kartu rencana studi),KHS (kartu Hasil studi), data mahasiswa yang sudah lulus, data keuangan dll.

Dalam pelaksanaan program akademik IAIN Sultan Amai Gorontalo dalam pengamatan peneliti masih terdapat beberapa kendala. Kurikulum yang mengalami perbedaan antar angkatan, karena perbedaan kurikulum tersebut mengakibatkan ada mata kuliah yang sudah tidak dijadwalkan kembali yang pada akhirnya mahasiswa yang belum mengontrak mata kuliah tidak bisa mengambil/mengontrak mata kuliah tersebut. Dalam penulisan karya ilmiah terkadang judul dan kerangka pembahasan skripsi belum menyentuh dengan keahlian jurusan. Pembayaran SPP tidak tepat waktu juga mempengaruhi dan mengganggu proses perkuliahan. Sebagian mahasiswa kurang memahami prosedur mengurus administrasi misalnya pengurusan surat keterangan aktif kuliah, pengurusan surat cuti akademik, dll. Pembelanjaan KRS yang sering di abaikan oleh mahasiswa dan keterlambatan approval KRS yang dilakukan oleh dosen penasehat akademik sering mengakibatkan nama mahasiswa belum terdaftar di absen kelas. Mahasiswa tidak mengetahui siapa dosen pembimbingnya dan kurangnya konsultasi dengan dosen pembimbing, akibatnya bertemu dengan dosen pembimbing hanya untuk kebutuhan penandatanganan KRS. Kurikulum yang mengalami perbedaan antar angkatan, karena perbedaan kurikulum tersebut mengakibatkan ada mata kuliah yang sudah tidak dijadwalkan kembali yang pada akhirnya mahasiswa yang belum mengontrak mata kuliah tidak bisa mengambil/mengontrak mata kuliah tersebut. 
Berdasarkan uraian dan penjelasan latar belakang masalah diatas rumusan masalah sekaligus sebagai batasan masalah pada penelitian ini adalah:

1. Apakah terdapat pengaruh penerapan program akademik terhadap mutu pelayanan mahasiswa?

2. Apakah terdapat pengaruh aplikasi SIAKAD terhadap mutu pelayanan mahasiswa?

3. Apakah terdapat pengaruh penerapan program akademik dan aplikasi SIAKAD terhadap mutu pelayanan mahasiswa?

\section{Kerangka Pikir}

Gambar.

\section{Kerangka Pikir}

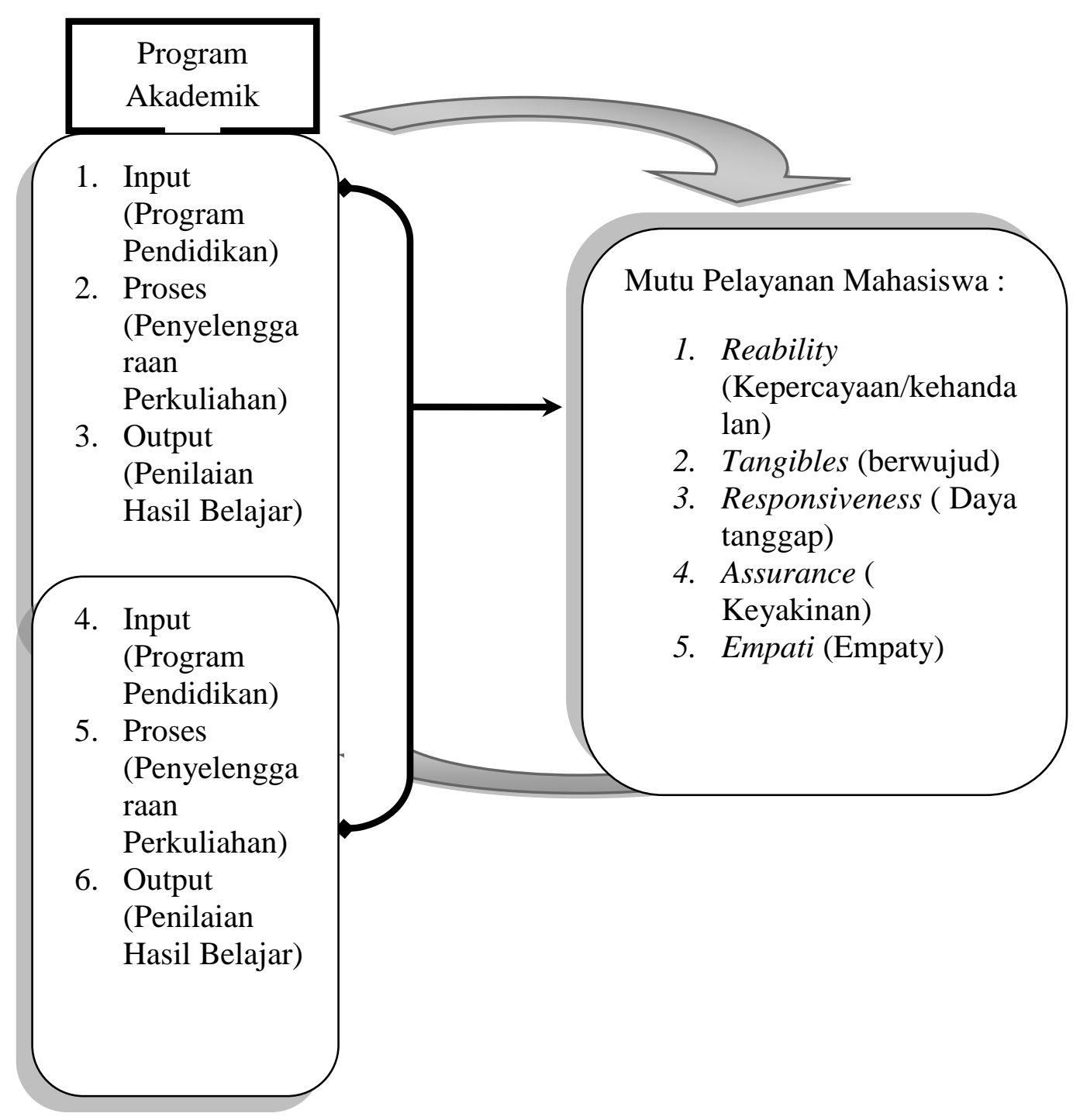




\section{Hipotesis Penelitian}

Berdasarkan kerangka pikir diatas, maka dapat dirumuskan hipotesis penelitian sebagai berikut :

1. Program akademik berpengaruh Positif secara signifikan terhadap Mutu pelayanan mahasiswa.

2. Aplikasi SIAKAD berpengaruh Positif secara signifikan terhadap Mutu pelayanan mahasiswa.

3. Program akademik dan Aplikasi SIAKAD berpengaruh Positif secara signifikan terhadap Mutu pelayanan mahasiswa.

\section{Metode Penelitian}

Pendekatan yang digunakan dalam penelitian ini adalah pendekatan kuantitatif. Jumlah populasi berjumlah 2.140 orang yang terdiri dari 6 prodi di Fakultas Ilmu Tarbiyah dan keguruan, peneliti melakukan penarikan sampel sebagai perwakilan dari jumlah populasi yang ada. Untuk populasi dengan ukuran kurang dari seratus, sampel dapat diambil seluruhnya. Namun dalam penelitian ini peneliti mengambil ukuran sampel menggunakan rumus Burhan Bungin dengan rumus sebagai berikut: ${ }^{6}$

$$
n=\frac{N}{N \cdot d^{2}+1}
$$

Dimana :

$$
\begin{aligned}
& \mathrm{n}=\text { Ukuran sampel } \\
& \mathrm{N}=\text { Ukuran Populasi } \\
& \mathrm{d}=\text { Nilai presisi/ketepatan meramal }
\end{aligned}
$$

Tarif kesalahan yang diambil adalah $10 \%(0,01)$ pertimbangannya adalah rumus ini sederhana dan untuk mendapatkan hasil yang pasti dari keseluruhan mahasiswa yang diteliti secara akurat.

Dari keterangan diatas maka dapat diperoleh sampel sebagai berikut:

Diketahui: $\mathrm{N}=2.140, \mathrm{~d}=10 \%$

Penyelesaiannya:

$$
n=\frac{2140}{(2140) \cdot(0,1)^{2}+1}=\frac{2140}{22.40}=95.54
$$

${ }^{6}$ Bungi, Burhan Dalam Herson Anwar dan Lian G. Otaya,statistika Pendidikan "teori dan aplikasi,(Cet.1 Gorontalo:Sultan Amai Press:2015)h.65 
Sampel penelitian 95.54 (dibulatkan menjadi 96 mahasiswa), kemudian penentuan ukuran sampel secara proporsional random sampling memakai rumusan alokasi proporsional sebagai berikut ${ }^{7}$ :

$$
n_{i}=\frac{N_{i}}{N} \cdot n
$$

Dimana :

$\mathrm{n}_{\mathrm{i}}=$ Jumlah sampel menurut stratum

$\mathrm{n}$ = Jumlah sampel seluruhnya

$\mathrm{N}_{\mathrm{i}}=$ Jumlah populasi menurut stratum

$\mathrm{N}$ = Jumlah populasi seluruhnya dari rumus diatas diperoleh sampel berdasarkan masing-masing strata sebagai berikut :

$$
\begin{aligned}
& \text { PAI }=673: 2140 \times 96=30 \text { orang } \\
& \text { MPI }=737: 2140 \times 96=33 \text { orang } \\
& \text { PBA }=122: 2140 \times 96=5 \text { orang } \\
& \text { PBI }=166: 2140 \times 96=7 \text { orang } \\
& \text { PGMI }=329: 2140 \times 96=15 \text { orang } \\
& \text { PIAUD }=\frac{113: 2140 \times 96=5 \text { orang }}{\text { Jumlah }=95 \text { Orang }}
\end{aligned}
$$

Dalam penelitian ini terdapat 3 (tiga) variabel penelitian,variabel pertama adalah Program akademik, variabel kedua Aplikasi SIAKAD, yang bersifat independen yaitu variabel yang mempengaruhi dan penyebab terjadinya perubahan. Variabel ketiga Mutu Pelayanan Mahasiswa yang bersifat Dependen (Terikat) yaitu variabel yang dipengaruhi.

Pengumpulan data penulis menggunakan angket, dan jenis analisis yang digunakan yaitu berupa analisis regresi Linear Sederhana dan Regresi Linear Berganda. Data - data yang dianalisis secara kuantitatif yaitu dengan menggunakann sistem model statistik dengan program (SPSS.16). Model Persamaan dalam penelitian ini adalah :

$$
\mathbf{Y}=\mathbf{a}+\mathbf{b} 1 \mathrm{X} 1+\mathbf{b} 2 \mathrm{X} 2
$$

$\mathrm{Y}=$ Subyek dalam variabel dependen yang diprediksi $\mathrm{X} 1$ dan $\mathrm{X} 2$ variabel Independen

$\mathrm{a}=$ Harga $\mathrm{Y}$ ketika harga $\mathrm{X}=0$ (harga konstanta)

$\mathrm{b}=$ Angka arah atau koefisien regresi, yang menunjukan angka peningkatan ataupun penurunan variabel dependen yang didasarkan pada perubahan variabel independen. Bila (+) arah garis naik dan bila (-) arah garis turun.

\footnotetext{
7 Riduwan \& Akron Dalam Herson Anwar Lian G. Otaya,statistika Pendidikan "teori dan aplikasi,(Cet.1 Gorontalo:Sultan Amai Press:2015)h.71
} 


\section{Uji F}

Hipotesis Statistiknya dinyatakan sebagai berikut :

Rumus $\mathrm{H}_{0}: \rho=0$ tidak terdapat pengaruh antara Program Akademik dan Aplikasi

SIAKAD dengan Mutu Pelayanan Mahasiswa di Fakultas Ilmu Tarbiyah dan Keguruan IAIN Sultan Amai Gorontalo

Rumus $\mathrm{H}_{\mathrm{a}}: \rho \neq 0$ terdapat pengaruh antara Program Akademik dan Aplikasi SIAKAD dengan Mutu Pelayanan Mahasiswa di Fakultas Ilmu Tarbiyah dan Keguruan IAIN Sultan Amai Gorontalo

Kaidah keputusan :

Jika nilai $F_{\text {hitung }}>F_{\text {tabel }}$, maka Ho ditolak dan Ha diterima, artinya koefisien regresi signifikan.

Jika nilai $\mathrm{F}_{\text {hitung }}<\mathrm{F}_{\text {tabel, }}$, maka Ho diterima dan Ha ditolak, artinya koefisien regresi tidak signifikan.

Dengan tingkat Signifikansi $\alpha=5 \%$ dan degree of freedom (k) dan (n-k-1), dimana $\mathrm{n}$ adalah jumlah observasi dan $\mathrm{k}$ adalah variabel independen, maka nilai $\mathrm{F}_{\text {hitung }}$ dirumuskan sebagai berikut :

$$
\text { FHitung }=\frac{R^{2 /} k}{\left(1-R^{2}\right) /(n-k)}
$$

Dimana :

$\mathrm{R}^{2} \quad$ : R Square

n : Banyaknya Data

k : Banyaknya Variabel Independen

\section{HASIL PENELITIAN DAN PEMBAHASAN}

\section{A. Hasil penelitian}

Berdasarkan sejarahnya, Fakultas Ilmu Tarbiyah dan Keguruan tidak lepas dari terbentuknya Institut Agama Islam Negeri Sultan Amai Gorontalo. Tepatnya, 4 Januari 1969 M./8 Syawal 1388 H., H. Mukti Ali selaku Direktur Jenderal PTAI atas nama Menteri Agama RI. menandatangani Surat Keputusan penetapan Fakultas Tarbiyah UIG Status Terdaftar dengan Keputusan Menteri Agama RI Nomor 118 Tahun 1969. Oleh karena izin pendirian Perguruan Tinggi Islam dituntut harus berada di bawah bimbingan perguruan tinggi Islam yang sudah mapan, maka ditunjuklah IAIN Alauddin Ujung Pandang sebagai pembina Fakultas Tarbiyah di Gorontalo. Menyetujui dan menetapkan 4 Januari 1969 sebagai tanggal/hari lahir IAIN Sultan Amai Gorontalo. 
Pada tahun 2013 Fakultas Tarbiyah dan Tadris berubah menjadi Fakultas Ilmu Tarbiyah dan Keguruan dan memiliki 6 Jurusan diantaranya :

1. Jurusan Pendidikan Agama Islam (PAI)

2. Jurusan Manajemen Pendidikan Islam (MPI)

3. Jurusan Pendidikan Bahasa Arab (PBA)

4. Jurusan Tadris Bahasa Inggris (TBI)

5. Jurusan Pendidikan Guru Madrasah Ibtidaiyah (PGMI)

6. Jurusan Pendidikan Guru Raudhatul Athfal (PGRA)

Populasi Jumlah Mahasiswa pada Fakultas Ilmu Tarbiyah dan Keguruan Tahun Akademik 2018/2019 sebanyak 2140 . Sampel yang diambil sebanyak 96 orang. Penyebaran angket disebar ke 6 Jurusan dimana pengambilan sampel menggunakan sample berstrata. Penulis mengambil data untuk uji coba instrumen ke mahasiswa di 6 (enam) jurusan sebagai bahan uji validitas instrumen penelitian. Hasil uji validitas tersebut kemudian dijadikan dasar dalam melakukan penelitian.

B. Pengujian Persyaratan Analisis data

1. Uji Validitas

Variabel penelitian yaitu variabel Program Akademik $\left(\mathrm{X}_{1}\right)$, Aplikasi SIAKAD (X2) dan Mutu Pelayanan Mahasiswa (Y) yang memiliki 37 pernyataan dan di sebarkan ke responden yang berjumlah 96 orang. Dari pernyataan (Koesioner) yang di sebarkan telah di uji validitasnya,sehingga pengujian dapat di lanjutkan.Hasil pengujian validitasnya yang telah dilakukan di peroleh hasil sebagai berikut :

Tabel 1

Uji Validitas

\begin{tabular}{|c|l|l|l|l|}
\hline $\begin{array}{c}\text { Variabel } \\
\text { sub Variabel }\end{array}$ & Item & T Tabel & R Hitung & Ket \\
\hline $\begin{array}{c}\text { Program } \\
\text { Akademik } \\
\left(\mathrm{X}_{1}\right)\end{array}$ & 1 & 0,202 & 0,549 & Valid \\
\cline { 2 - 5 } & 2 & 0,202 & 0,534 & Valid \\
\cline { 2 - 5 } & 3 & 0,202 & 0,003 & Tidak Valid \\
\cline { 2 - 5 } & 4 & 0,202 & 0,485 & Valid \\
\cline { 2 - 5 } & 5 & 0,202 & 0,602 & Valid \\
\cline { 2 - 5 } & 6 & 0,202 & 0,627 & Valid \\
\cline { 2 - 5 } & 7 & 0,202 & 0,315 & Valid \\
\hline
\end{tabular}




\begin{tabular}{|c|c|c|c|c|}
\hline & 8 & 0,202 & 0,639 & Valid \\
\hline & 9 & 0,202 & 0,544 & Valid \\
\hline & 10 & 0,202 & 0,444 & Valid \\
\hline & 11 & 0,202 & 0,472 & Valid \\
\hline & 12 & 0,202 & 0,571 & Valid \\
\hline & 13 & 0,202 & 0,751 & Valid \\
\hline \multirow{7}{*}{$\begin{array}{l}\text { Aplikasi } \\
\text { SIAKAD } \\
\text { (X2) }\end{array}$} & 14 & 0,202 & 0,424 & Valid \\
\hline & 15 & 0,202 & 0,359 & Valid \\
\hline & 16 & 0,202 & 0,882 & Valid \\
\hline & 17 & 0,202 & 0,372 & Valid \\
\hline & 18 & 0,202 & 0,808 & Valid \\
\hline & 19 & 0,202 & 0,457 & Valid \\
\hline & 20 & 0,202 & 0,799 & Valid \\
\hline \multirow{10}{*}{$\begin{array}{c}\text { Mutu } \\
\text { Pelayanan } \\
\text { Mahasiswa } \\
\text { (Y) }\end{array}$} & 21 & 0,202 & 0,611 & Valid \\
\hline & 22 & 0,202 & 0,625 & Valid \\
\hline & 23 & 0,202 & 0,514 & Valid \\
\hline & 24 & 0,202 & 0,744 & Valid \\
\hline & 25 & 0,202 & 0,753 & Valid \\
\hline & 26 & 0,202 & 0,802 & Valid \\
\hline & 27 & 0,202 & 0,670 & Valid \\
\hline & 28 & 0,202 & 0,645 & Valid \\
\hline & 29 & 0,202 & 0,839 & Valid \\
\hline & 30 & 0,202 & 0,687 & Valid \\
\hline
\end{tabular}




\begin{tabular}{|c|c|c|c|c|}
\hline \multirow{1}{*}{31} & 0,202 & 0,604 & Valid \\
\cline { 2 - 5 } & 32 & 0,202 & 0,579 & Valid \\
\cline { 2 - 5 } & 33 & 0,202 & 0,634 & Valid \\
\cline { 2 - 5 } & 34 & 0,202 & 0,447 & Valid \\
\cline { 2 - 5 } & 35 & 0,202 & 0,507 & Valid \\
\cline { 2 - 5 } & 36 & 0,202 & 0,556 & Valid \\
\cline { 2 - 5 } & 37 & 0,202 & 0,767 & Valid \\
\hline
\end{tabular}

Berdasarkan Tabel di atas dapat di simpulkan bahwa dari keseluruhuan Item pernyataan dari ketiga variabel, pada item pernyataan nomor 3 variabel $\mathrm{X}_{1}$ dianggap tidak valid dan item pernyataan ini tidak diteruskan. Sementara item pernyataan pada semua variabel yang terdapat dalam daftar pernyataan (kuesioner) di anggap valid karena $r$ menunjukan positif atau $\mathrm{T}$ hitung $>\mathrm{T}$ tabel adalah 2,202, sehingga pengujian dapat di lanjutkan pada pengujian reliabiltas

\section{Uji Releabilitas}

Pengujian realibilitas dilakukan dengan menggunakan rumus Alpha Crombach. Suatu instrumen dinyatakan reliabel bila koefisien reliabilitas minimal $0,6{ }^{8}$ Untuk memudahkan menghitung reliabilitas instrumen, peneliti menggunakan bantuan Statistical Product and Service Solution (SPSS) versi 16.0 for windows. Berdasarkan hasil perhitungan uji reliabilitas diperoleh nilai $r$ sebagai berikut.

Tabel 2.1

\section{Hasil Uji Reabilitas Variabel Program Akademik (X1)}

\section{Reliability Statistics}

\begin{tabular}{|c|r|}
\hline $\begin{array}{c}\text { Cronbach's } \\
\text { Alpha }\end{array}$ & N of Items \\
\hline .737 & 13 \\
\hline
\end{tabular}

\footnotetext{
${ }^{8}$ Sugiono, Metode Penelitian Manajemen (Bandung: Alfabeta,2013), h. 220
} 
Hasil Uji Reabilitas Variabel Aplikasi SIAKAD (X2)

Hasil Uji Reabilitas Variabel Mutu Pelayanan Mahasiswa (Y)

\section{Reliability Statistics}

\begin{tabular}{|c|r|}
\hline $\begin{array}{c}\text { Cronbach's } \\
\text { Alpha }\end{array}$ & N of Items \\
\hline .757 & 18 \\
\hline
\end{tabular}

Berdasarkan hasil table out put tentang Reliability statistics variable Program Akademik (X1), Aplikasi SIAKAD (X2) dan Mutu Pelayanan Mahasiswa (Y) didapat masing-masing variable koefisien Alpha Cronbach yaitu sebesar $0.737\left(\mathrm{X}_{1}\right), 0.740\left(\mathrm{X}_{2}\right)$ dan $0,757(\mathrm{Y})$. Hasil ini menunjukkan bahwa instrument tersebut reliabel karena $0.737\left(\mathrm{X}_{1}\right), 0.740\left(\mathrm{X}_{2}\right), 0.757>0.6$.

\section{Uji Regresi berganda}

Untuk hasil analisis pengaruh antara variable Program Akademik (X1) dan

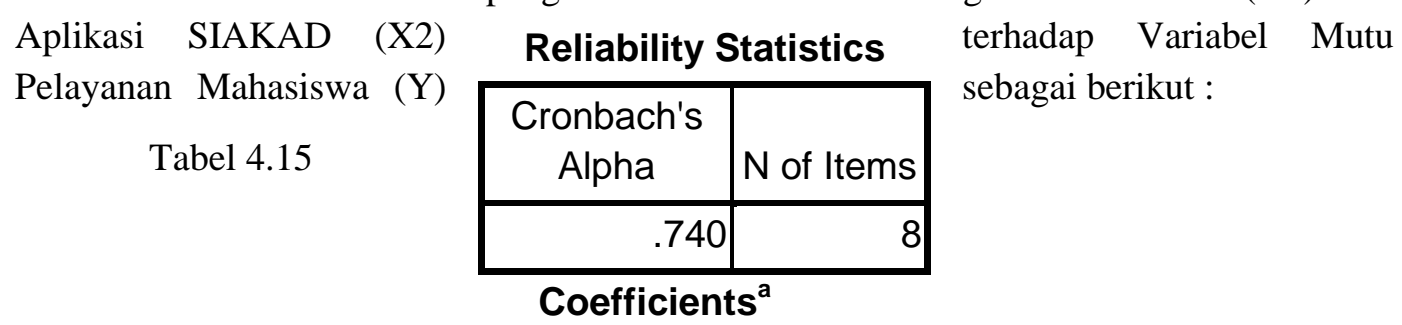

\begin{tabular}{|c|c|c|c|c|c|c|}
\hline \multirow{2}{*}{\multicolumn{2}{|c|}{ Model }} & \multicolumn{2}{|c|}{$\begin{array}{l}\text { Unstandardized } \\
\text { Coefficients }\end{array}$} & \multirow{2}{*}{\begin{tabular}{|c}
$\begin{array}{c}\text { Standardiz } \\
\text { ed } \\
\text { Coefficient } \\
\text { s }\end{array}$ \\
Beta
\end{tabular}} & \multirow[b]{2}{*}{$t$} & \multirow[b]{2}{*}{ Sig. } \\
\hline & & B & Std. Error & & & \\
\hline \multirow[t]{3}{*}{1} & (Constant) & 9.952 & 5.075 & & 1.961 & .053 \\
\hline & $\begin{array}{l}\text { Program } \\
\text { Akademik }\end{array}$ & .478 & .178 & .268 & 2.684 & .009 \\
\hline & Aplikasi SIAKAD & 1.142 & .211 & .541 & 5.408 & .000 \\
\hline
\end{tabular}

a. Dependent Variable: Mutu Pelayanan Mahasiswa

Berdasarkan tabel Coefficient di atas dapat digambarkan bahwa persamaan regresi dalam penelitian ini, yakni sebagai berikut: $Y=a+b_{1} X_{1+} b_{2} X_{2}=9,952+0,478 X_{1}+$ $1,142 \mathrm{X}_{2}$. 
Konstanta sebesar 9,952 menyatakan jika tidak ada kenaikan nilai dari variabel penerapan sistem Program Akademik (variabel $\mathrm{X}_{1}$ ), maka nilai Mutu Pelayanan Mahasiswa (variabel Y) adalah 9,952 . Koefisien regresi variable program Akademik $\left(\mathrm{X}_{1}\right)$ sebesar 0,478 menyatakan bahwa setiap penambahan $1 \%$ nilai penerapan Program Akademik akan memberikan peningkatan nilai Mutu pelayanan Mahasiswa (Y) sebesar 0,478 .

Untuk koefisien regresi variable Aplikasi SIAKAD $\left(\mathrm{X}_{2}\right)$ sebesar 1,142 menyatakan bahwa setiap penambahan $1 \%$ nilai Aplikasi SIAKAD $\left(\mathrm{X}_{2}\right)$ maka akan memberikan peningkatan nilai Mutu pelayanan Mahasiswa (Y) sebesar 1,142.

\section{PENGUJIAN HIPOTESIS}

\section{Pengujian Hipotesis Program Akademik (X1)}

Berdasarkan tabel Coefficient di atas, pada kolom Unstandardized Coefficient, nilai $\mathrm{X}_{1}$ (Program Akademik ) sebesar 2.684 tingkat signifikansi menggunakan $\alpha=$ $0,05 \%$ dan tabel distribusi t dicari pada $\alpha=0,05: 2$ derajat kebebasan (dk) n-k-1 $=96-2$ $1=93$ dan $\alpha=0.05$, dalam rumus $(\mathrm{t}$ tabel $=\mathrm{t}(\alpha / 2 ; \mathrm{n}-\mathrm{k}-1)$ atau $(\mathrm{t}$ tabel $=\mathrm{t}(0.05 / 2$; $(96-2-1)=0.025 ; 93)$ sehingga diperoleh nilai $t_{\text {tabel }}=1$,989. nilai $t_{\text {hitung }}>t_{\text {tabel }}$ atau $2.684>1,989$, maka $\mathrm{H}_{0}$ ditolak dan $\mathrm{Ha}$ diterima, yang berarti koefisen regresi berpengaruh secara signifikan.

\section{Pengujian Hipotesis Aplikasi SIAKAD (X2)}

Berdasarkan tabel Coefficient di atas, pada kolom Unstandardized Coefficient, nilai $\mathrm{X}_{2}$ (Aplikasi SIAKAD) sebesar 5.408 tingkat signifikansi menggunakan $\alpha=0,05 \%$ dan tabel distribusi t dicari pada $\alpha=0,05: 2$ derajat kebebasan $(\mathrm{dk}) \mathrm{n}-\mathrm{k}-1=96-2-1=93$ dan $\alpha=0.05$, dalam rumus $(\mathrm{t}$ tabel $=\mathrm{t}(\alpha / 2 ; \mathrm{n}-\mathrm{k}-1)$ atau $(\mathrm{t}$ tabel $=\mathrm{t}(0.05 / 2 ;(96-2-1$ )$=0.025 ; 93)$ sehingga diperoleh nilai $t_{\text {tabel }}=1,989$. nilai $t_{\text {hitung }}>t_{\text {tabel }}$ atau $5.408>1,989$, maka $\mathrm{H}_{0}$ ditolak dan $\mathrm{Ha}$ diterima, yang berarti koefisen regresi berpengaruh secara signifikan.Dengan demikian terbukti berdasarkan Uji t bahwa Aplikasi SIAKAD $\left(\mathrm{X}_{2}\right)$ berpengaruh secara signifikan terhadap Mutu Pelayanan Mahasiswa (Y) di Fakultas Ilmu Tarbiyah dan Keguruan IAIN Sultan Amai Gorontalo 


\section{Pengujian Hipotesis secara bersama sama}

Hasil output analisis regresi diketahui nilai $\mathrm{F}$ adalah sebagai berikut :

\begin{tabular}{|c|c|c|c|c|c|c|}
\hline \multicolumn{7}{|c|}{ ANOVA $^{b}$} \\
\hline \multicolumn{2}{|c|}{ Model } & $\begin{array}{l}\text { Sum of } \\
\text { Squares }\end{array}$ & $d f$ & $\begin{array}{l}\text { Mean } \\
\text { Square }\end{array}$ & $F$ & Sig. \\
\hline 1 & Regression & 2259.075 & 2 & 1129.538 & 63.962 & $.000^{\circ}$ \\
\hline & Residual & 1642.331 & 93 & 17.659 & & \\
\hline & Total & 3901.406 & 95 & & & \\
\hline
\end{tabular}

a. Predictors: (Constant), Aplikasi SIAKAD, Program

Akademik

b. Dependent Variable: Mutu Pelayanan Mahasiswa

Berdasarkan Tabel ANOVA diatas diperoleh $F_{\text {hitung }}$ sebesar 63.962 .Tingkat Signifikansi menggunakan $\alpha=0,05$ dan tabel distribusi t dicari pada $\alpha=0,05: 2$ derajat kebebasan (dk) $\mathrm{n}-\mathrm{k}-1=96-2-1=93$ dan $\alpha=0.05$, dalam rumus $(\mathrm{t}$ tabel $=\mathrm{t}(\alpha / 2 ; \mathrm{n}-\mathrm{k}-$ 1) atau $\left(\mathrm{t}\right.$ tabel $=\mathrm{t}(0.05 / 2 ;(96-2-1)=0.025 ; 93)$ sehingga diperoleh nilai $\mathrm{t}_{\text {tabel }}=1,989$. nilai $\mathrm{F}_{\text {hitung }}>\mathrm{t}_{\text {tabel }}$ atau $63.962>1,989$, maka $\mathrm{H}_{0}$ ditolak dan Ha diterima, yang berarti koefisen regresi berpengaruh secara signifikan.Dengan demikian terbukti berdasarkan Uji F bahwa Program AKademik $\left(\mathrm{X}_{1}\right)$ dan Aplikasi SIAKAD $\left(\mathrm{X}_{2}\right)$ berpengaruh secara signifikan terhadap Mutu Pelayanan Mahasiswa (Y) di Fakultas Ilmu Tarbiyah dan Keguruan IAIN Sultan Amai Gorontalo

\section{HASIL PEMBAHASAN}

Sebagai salah satu Perguruan tinggi Islam yang ada di Gorontalo IAIN Sultan Amai Gorontalo merupakan kelanjutan pendidikan menengah yang diselenggarakan untuk mempersiapkan peserta didik untuk menjadi anggota masyarakat yang memiliki kemampuan akademis dan profesional yang dapat menerapkan, mengembangkan dan menciptakan ilmu pengetahuan, teknologi dan kesenian.Perguruan tinggi yang cukup besar tentunya harus memiliki kualitas yang baik supaya dapat menarik minat calon mahasiswa. Karenanya, perguruan tinggi harus bisa memberikan pelayanan terbaik bagi mahasiswa maupun calon mahasiswa.

Hadirnya Aplikasi SIAKAD ( Sistem Informasi Akademik) telah menjawab .perkembangan teknologi dan informasi di perguruan tinggi khususnya di IAIN Sultan Amai Gorontalo. Penerapan Aplikasi SIAKAD merupakan sebuah perangkat untuk mendukung penyelenggaraan pendidikan yang digunakan untuk menyampaikan program 
akademika kepada seluruh civitas akademika dan stakeholder dan lain lain, sehingga dapat menyediakan layanan akademik yang lebih baik, efektif dan efisien.

Merujuk dari hasil hipotesis yang diajukan dalam penelitian ini menunjukan bahwa Program Akademik dan Aplikasi SIAKAD memiliki hubungan keterikatan yang sangat erat dengan Mutu Pelayanan Mahasiswa di Fakultas Ilmu Tarbiyah dan Keguruan IAIN Sultan Amai Gorontalo. Hal ini membuktikan bahwa semakin baik Program Akademik dan Aplikasi SIAKAD maka semakin baik pula mutu pelayanan mahasiswa. Berdasarkan hasil hipotesis ini ,menunjukan Program Akademik dan Aplikasi SIAKAD berpengaruh terhadap Mutu Pelayanan mahasiswa, "Diterima". Dimana dari hasil perhitungan diperoleh $\mathrm{F}_{\text {hitung }}>\mathrm{F}_{\text {tabel }}$ yaitu $63.962>1,989$, maka $\mathrm{H}_{0}$ ditolak dan Ha diterima, dengan demikian berarti Program akademik dan Aplikasi SIAKAD berpengaruh terhadap Mutu Pelayanan Mahasiswa.

Implikasi dari penelitian ini adalah untuk dapat meningkatkan mutu pelayanan bagi mahasiswa. Yakni kesesuaian antara program akademik yang di jalankan dan Aplikasi SIAKAD sebagai sarana penunjangnya. Agar Kesesuaian ini dapat mewakili keinginan dan harapan dari pengguna (User). Keberhasilan suatu program bukan terletak pada programnya, akan tetapi lebih ditentukan pada semangat kerja pelaku dalam merealisasi program itu. Dengan adanya program akademik dan Aplikasi SIAKAD diharapkan dapat mendigitalisasi data, kurikulum, mata kuliah, dosen, tenaga administrasi,serta memberikan kemudahan akses dan diharapkan dapat mendukung penerapan sistem di lapangan. Peningkatan sosialisasi kepada user dan mahasiswa agar program akademik berjalan dengan lancar dan bermanfaat. Perlu adanya pengembangan integrasi dengan sistem akademik (SIAKAD), sehingga dapat melengkapi data penunjang sistem informasi.

\section{KESIMPULAN}

Berdasarkan hasil penelitian dan pembahasan yang telah dikemukakan sebelumnya,diketahuibahwa :

1. Program Akademik berpengaruh terhadap Mutu Pelayanan mahasiswa, setelah diuji dengan menggunakan rumus regresi sederhana $Y=a+b_{x}=6.461+1.189 X_{1}$. Hal ini membuktikan bahwa Program Akademik memiliki pengaruh yang signifikan terhadap Mutu Pelayanan Mahasiswa, serta mengakibatkan peningkatan sebesar 1.189 pada konstanta 25.791

2. Aplikasi SIAKAD berpengaruh terhadap Mutu Pelayanan Mahasiswa, setelah diuji dengan menggunakan rumus regresi sederhana $Y=a+b_{x}=20.292+1.562$ $\mathrm{X}_{2}$. Hal ini membuktikan bahwa Aplikasi SIAKAD memiliki pengaruh yang 
signifikan terhadap Mutu Pelayanan Mahasiswa, serta mengakibatkan peningkatan sebesar 1.562 pada konstanta 20.292

3. Program Akademik dan Aplikasi SIAKAD berpengaruh terhadap Mutu Pelayanan Mahasiswa, setelah diuji dengan menggunakan rumus regresi berganda $\mathrm{Y}=\mathrm{a}+\mathrm{b}_{1} \mathrm{X}_{1+} \mathrm{b}_{2} \mathrm{X}_{2}=9,952+0,478 \mathrm{X}_{1}+1,142 \mathrm{X}_{2}$. Hal ini membuktikan bahwa Program Akademik dan Aplikasi SIAKAD memiliki pengaruh yang signifikan terhadap Mutu Pelayanan Mahasiswa, program Akademik mengakibatkan peningkatan sebesar 0,478 dan Aplikasi SIAKAD mengakibatkan peningkatan sebesar 1,142 pada konstanta 9,952. Hal ini dibuktikan juga dengan pengujian hipotesis dimana masing - masing uji parsial $t_{\text {hitung }}>\mathrm{t}_{\text {tabel, }}$ yaitu Variabel X1 $(2.684>1,989)$ dan $\mathrm{X} 2(5.408>1,989)$. Kemudian pada pengujian secara bersama - sama di dapat $\mathrm{F}_{\text {hitung }}>\mathrm{F}_{\text {tabel }}$ atau $63.962>1,989$, maka H0 di tolak dan Ha di terima.

Maka dari hasil hipotesis penelitian ini menunjukan bahwa variable Program Akademik dan Aplikasi SIAKAD memberikan pengaruh signifikan terhadap Mutu Pelayanan Mahasiswa di fakultas Ilmu Tarbiyah dan Keguruan IAIN Sultan Amai Gorontalo.

\section{DAFTAR PUSTAKA}

Daryanto, Administrasi Pendidikan, (Jakarta: Rineka Cipta, 2011

Edy Sutrisno, Manajemen Sumber Daya Manusia, Cetakan ke-5, Jakarta: Kencana, 2013

Bungi, Burhan Dalam Herson Anwar dan Lian G. Otaya,statistika Pendidikan "teori dan aplikasi, Cet.1 Gorontalo:Sultan Amai Press:2015

Riduwan, Metode dan Teknik Menyusun Tesis,Bandung: Alfabeta,2010 Cet. VII

Ridwan Tohopi dkk, Pedoman Akademik IAIN Sultan Amai Gorontalo.Gorontalo :2014

Riduwan \& Akron Dalam Herson Anwar Lian G. Otaya,statistika Pendidikan "teori dan aplikasi, Cet.1 Gorontalo:Sultan Amai Press:2015

Sudiyono, Manajemen Pendidikan Tinggi, Jakarta:Rineka Cipta, 2004

Sugiono, Metode Penelitian Manajemen, Bandung: Alfabeta,2013 